\section{BEVEZETÉS AZ ÚJ EURÓPAI UNIÓS BIZTOSÍTÁSI ÉRTÉKESÍTÉSI (IDD) IRÁNYELVBE}

Lencsés Katalin (Magyar Biztositók Szövetsége, a Biztositás és Kockázat szerkesztője) katalin.lencses@mabisz.hu

\section{ÖSSZEFOGLALÓ}

A biztosítási értékesítésről szóló új IDD irányelv 2016. február 22-én került kihirdetésre, és a jelenleg még hatályban lévő IMD irányelv helyébe lépve, európai uniós szinten szabályozza majd a biztosítási termékek értékesítését. A tagállamoknak az IDD-t két éven belül, vagyis 2018. február 23-ig kell átültetniük a nemzeti jogrendjükbe. Az új irányelv legfontosabb célja az egységes ügyfélvédelmi szabályok megteremtése valamennyi értékesítési csatorna vonatkozásában. Az IDD minimum harmonizációs jogszabály, így a tagállamok az abban rögzítetteknél szigorúbb szabályokat is alkalmazhatnak, amennyiben ezt a fogyasztóvédelem megköveteli. Jelen cikk az új uniós jogszabály legfontosabb tudnivalóit foglalja össze, és egyben listázza a kapcsolódó hazai feladatokat.

\section{SUMMARY}

The Insurance Distribution Directive (IDD) came into force on 22 February 2016 and updates the Insurance Mediation Directive (IMD), which set out a framework for regulating EU insurance distribution. Member states have two years to transpose the IDD into national laws, i.e. before 23 February 2018. The new directive intends to ensure a level playing field between all participants involved in distributing insurance products in order to strengthen consumer protection. The IDD is aimed at minimum harmonization and should therefore not preclude Member States from introducing more stringent provisions in order to protect customers. The present article summarize the main aspects of the new European legislation, and listing the related tasks on national level.

Kulcsszavak: IDD, biztosítás értékesítés, Európai Unió

Keywords: IDD, insurance distribution, European Union

JEL: G22, G38

DOI: $10.18530 /$ BK.2016.2.16

http://dx.doi.org/1018530/BK.2016.2.16

\section{Előszo}

Szokatlannak tekinthetö módon jelen cikk azzal indul, hogy a szerzö megköszöni a lektoroknak, Gordos Józsefnek (NGM), Haraszti Zsófiának (Magyarország brüsszeli Állandó Képviselete) és Nagy Koppánynak (MNB), hogy figyelmes, értö módon olvasták az írást, és jobbitó észrevételeikkel hozzájárultak a végleges szöveg kialakulásához. A közös munka hangsúlyozása ebben az esetben azért is nagyon fontos, mivel egy olyan új, európai uniós jogszabályról van szó, melynek szövegével csak most kezdenek el érdemben ismerkedni a tagállamok, így azoknak, akik elsőként látnak neki a feldolgozás gyötrelmes munkájának, meg kell küzdeniük a sokszor nehezen értelmezhetö és olykor nem is feltétlenül egyértelmü rendelkezésekkel, melyeket többnyire az IDD kapcsán született tagállami kompromisszumok eredményeztek.

A Biztositás és Kockázat szerkesztősége ezt a cikket a fentiek jegyében figyelemfelhivásnak és gondolatébresztönek is szánja abban a reményben, hogy a szakma, miután alaposabban is tanulmányozta az IDD szövegét, a kapcsolódó gondolatait, értelmezéseit és problémafelvetéseit jelen kiadvány hasábjain keresztül is megosztja az olvasótáborral.

Várjuk tehát a témához kapcsolódó cikkeket, legyenek azok az irányelvet átfogóan érintö írások vagy annak egy-egy elemét megvilágitó elemzések.

\section{• Előzmény}

A közelmúltban kihirdetett új, uniós, a biztosítási értékesítésről szóló irányelv - melyet a szakmában legtöbben még az angol elnevezésből származó IDD ${ }^{1}$ betűszóval emlegetnek előzménye a jelenleg még hatályban lévő és 2018. február 23-ával hatályát vesztő 2002/92/EK irányelv (közismertebb nevén IMD), mely a biztosítások közvetítését szabályozza. Az IMD irányelvről az idők során kiderült, hogy több szempontból is módosításokra szorul. Részben mivel a tagállamok azt eltérő módon ültették át, az európai jogalkotó szükségesnek látta az ügyfélvédelem szintjének egységesítését mind az egyes tagállamok, mind a különböző értékesítési csatornák vonatkozásában. További ok volt az újragondolásra, hogy a 2008-as pénzügyi válság felhívta a figyelmet azokra a fogyasztóvédelmi problémákra, melyek elsősorban a befektetési termékeket érintették, és ennek kapcsán a befektetéssel kombinált életbiztosítások is az érdeklődés középpontjába kerültek. Mivel az érintett biztosítói termékcsoport szabályai jelenleg nincsenek összhangban más befektetési termékek (pl. befektetési jegyek) szabályaival, ezért ezek egységesítése is elvárásként fogalmazódott meg az Európai Unió szintjén.

Az IMD irányelv újragondolása már 2010-ben megkezdődött, ennek részét képezték a nyilvános konzultációk is, a Bizottság jogszabályjavaslatát pedig 2012 júliusában nyújtotta be a Parlamentnek és a Tanácsnak. A végleges szöveg elfogadására ugyanakkor csak 2015 végén került sor. Az eljárás elhúzódása több okra is visszavezethető, ezek közül kétségkívül az egyik legjelentősebb az volt, hogy az egyes tagállamok a szabályozás különböző szintjére jutottak az idők folyamán, és mindenki a saját megoldásait szerette volna viszontlátni uniós 
szinten. A tárgyalások során végül elfogadott kompromisszum értelmében az elvárt minimum szabályok viszonylag kisebb változásokat jelentenek a ma érvényes szabályozáshoz képest, az akár jelentősnek is tekinthető szigorítási lehetőségeket pedig tagállami opcióként határozta meg a jogalkotó.

Jelen összefoglalónak nem célja az új jogszabály részletes elemzése vagy értelmezése, ez a későbbiekben a jogalkotó feladata lesz, mely munkálatok során támaszkodik a biztosítási szakma együttműködésére is. A már ismert IDD szöveget tovább pontosítják majd az uniós szinten későbbiekben megszülető második szintű végrehajtási rendeletek és harmadik szintű ajánlások is, ez a cikk tehát már csak ezért sem tud teljes körü elemzésre vállalkozni. $\mathrm{Az}$ írás célja sokkal inkább az, hogy első és általános képet adjon az új irányelvről, elsősorban a fontosabb változásokra összpontosítva.

\section{- Általános tudnivalók}

Az IDD 2016 februárjában került kihirdetésre, és a tagállamoknak 2018. február 22-ig kell átültetniük a nemzeti jogrendjükbe. Az irányelv hatálya átfedésben van a PRIIPs rendelettel ${ }^{2}$ a biztosítási alapú befektetési termékek vonatkozásában. A PRIIPs rendelet a lakossági befektetési csomagtermékek (Packaged Retail and Insurance-based Investment Products), ezen belül a biztosítási alapú befektetési termékek kulcsfontosságú terméktájékoztatási szabályait rögzíti, egy európai szinten egységesített dokumentum segítségével.

\section{Az európai jogalkotó célja az ügyfelek azonos szintü \\ védelmének biztosítása.}

További tudnivaló, hogy a szöveg már beépítette a korábban külön eljárásban elfogadott MiFID2 (IMD1.5) rendelkezéseit is, melyek szintén a biztosítási alapú PRIIPs termékeket érintik, és melyek lényegében az érdekkonfliktus kezelésének MiFID szabályait ültetik át a biztosítások ezen termékcsoportjára. (A hivatkozott szabályok az IDD VI. fejezetében találhatóak meg. Az Európai Bizottság legutóbbi tájékoztatása értelmében az IMD1.5 szabályok még az IDD alkalmazását megelőzően hatályukat vesztik.)

Az új szabályozással az európai jogalkotó célja az ügyfelek azonos szintű védelmének biztosítása (értékesítési csatornától függetlenül), az ügyfelek bizalmának megerősítése, valamint az értékesítésre vonatkozó szabályok egységesebbé tétele. Az IDD-től a jogalkotó azt is várja, hogy az összehasonlíthatóság biztosításával (ld. PID és KID később), az ügyfél az értékesítő segítségével a folyamat végén jobb döntést hoz, és a számára megfelelő terméket választja ki a kínálatból. Szintén a fogyasztó érdekeire figyelve, a jogalkotó továbbra is lehetővé teszi azt az eddigi gyakorlatot, hogy a biztosítási termékek változatos csatornákon keresztül legyenek elérhetőek az ügyfelek számára. A biztosítók nyeresége a megnövekedett ügyfélbizalom és az ennek nyomán várhatóan kiszélesedő piaci lehetőségek. Ez utóbbihoz hozzájárulhat a határon átnyúló eladások növekedése is, amit az IDD rendelkezések előmozdítani igyekeznek.
Mindez a döntéshozók reményei szerint ösztönzőleg hat a versenyre és a piaci innovációra, valamennyi piaci szereplő érdekét szolgálva ezzel.

Mivel minimum harmonizációs irányelvről van szó, a tagállamok az irányelv szintjén elfogadott minimum elvárásokhoz képest szigorúbb szabályokat is megállapíthatnak. Figyelemre méltó, hogy ezt a lehetőséget megerősítve a szöveg több helyen kifejezetten nevesíti a tagállami szigorítás lehetőségét.

A Szolvencia II szabályozás óta az a jogalkotási technika sem ismeretlen a biztosítási piac számára, hogy több témában második, illetve harmadikszintü szabályok születnek, melyek pontosítják az első szabályozási szint általánosabb elvárásait. Ez az ún. Lámfalussy-eljárás, melynek lényege, hogy az első szinten (az Európai Unió Tanácsa és az Európai Parlament) az alapelveket tartalmazó keretszabály születik meg, melyet a technikai részletszabályokat rögzítő második szintű végrehajtási rendeletek és harmadik szintű iránymutatások egészítenek ki. Ez utóbbiak megalkotója az Európai Bizottság, ahol a biztosítási szakterület esetében a munkát az Európai Biztosítás- és Foglalkoztatóinyugdíj-hatóság (EIOPA, European Insurance and Occupational Pensions Authority) segíti. A technikai munka elkezdésére vonatkozó felkérést az Európai Bizottság 2016 februárjában küldte meg az EIOPA részére, amely 2017. február 1-jéig technikai javaslatot készít és nyújt be a Bizottság részére. A Bizottság az EIOPA technikai javaslata alapján delegált jogi aktusok formájában fogadja el a részletszabályokat. Az IDD felhatalmazza továbbá az EIOPA-t szabályozástechnikai végrehajtás technikai sztenderdtervezetek, valamint iránymutatások kialakítására is.

Jelen cikk a második, illetve harmadik szinten megszülető szabályokat külön kiemeli, a hogy a tagállami opciókat is (az egyes eseteket eltérő színkóddal jelölve). Jól látható, hogy ezek a színes kiemelések egyre szaporodnak a szövegben, ahogy közeledünk a PRIIPs termékek értékesítésének megerősített szabályozása felé.

Az IMD újragondolásának fontos célja volt a fogyasztói jogok megerősítése és egységesítése. Az IDD ennek megfelelően külön jelzi, ahol az elvárásokat nem kell alkalmazni a nagykockázatokra, illetve a szakmai ügyfelekre.

\section{- Hatály}

A biztosítási termékek rugalmasan, különböző értékesítési csatornákon keresztül érhetőek el, ami az ügyfelek érdekét szolgálja, amennyiben a fogyasztó azonos szintű védelemben részesül az értékesítési csatornától függetlenül. Az IDD ennek megfelelően meg kívánja teremteni az egyenlő feltételeket és az egyenlő feltételeken alapuló versenyt az egyes csatornák vonatkozásában, függetlenül attól, hogy valamely biztosítóhoz kötődő vagy attól független értékesítési csatornáról van-e szó. Az uniós szabályozó mindazonáltal igyekszik figyelemmel lenni arra, hogy a tagállamokban kialakult közvetítői csatornák rendkívül színesek, és sokszor egyedi, tagországi jellegzetességeket is mutatnak. 
Az IDD a „biztositási értékesités” átfogó fogalma alatt kétféle tevékenységet tart nyilván, a biztosítói értékesítést és a biztosításközvetítői tevékenységet. (Az IDD ugyanezeket a fogalmakat a viszontbiztosítási tevékenységre is értelemszerủen alkalmazza.)

1. Az IDD szélesebbre nyitotta a hatályt a most hatályos IMD irányelvhez képest és új elemként a szabályozás vonatkozik a biztositói értékesítésre is (online vagy alkalmazotton keresztül). Ugyanakkor néhány esetben elválnak a biztosítói és közvetítői értékesítésre vonatkozó szabályok, amit magyaráz, hogy biztosítói értékesítés esetén egyértelműen tisztázottak az érdekeltségi és felelősségi viszonyok. Fontos tehát figyelni arra, hogy mikor alkalmazza az irányelv az „értékesités” tágabb és a „közvetités” szűkebb fogalmát.

2. Természetesen hatály alá tartoznak a biztosításközvetítök is, ahol újdonság, hogy már ide értendőek az. ún. aggregátor, összehasonlító weboldalak is, amennyiben az ügyfélnek a folyamat végén közvetlenül vagy közvetve lehetősége van a szerződés megkötésére.

A biztosításközvetítők tevékenységét a jogszabály megkülönbözteti annak alapján, hogy milyen típusú a közvetített biztosítási termék, kapcsolódik-e más, nem biztosítási termékhez vagy szolgáltatáshoz, illetve hogy a közvetítés fötevékenységként vagy kiegészítő tevékenységként történik-e.

a) A kiegészítő tevékenységként végzett biztosításközvetítés bizonyos esetekben mentességet élvez, amennyiben teljesíti a mentesség feltételeit, vagyis a biztosítási díj nem haladja meg az irányelven rögzített összeget ${ }^{3}$, és a fedezet korlátozott.

b) A hatály alatt maradó kiegészítö biztosításközvetítő esetében az elvárások arányosan igazodnak ehhez a csatornához. Az IDD itt is rögzíti a három, együttesen teljesülö feltételt, amikor egy közvetítő ebbe a kategóriába sorolható ${ }^{4}$. Ez a feltételrendszer a következő: Az értékesítést végző személy fö tevékenysége nem a biztosítás értékesítése, csak bizonyos termékeket értékesít, melyek kiegészítő jellegüek valamely áruhoz vagy szolgáltatáshoz, és azok nem tartalmaznak életbiztosítási vagy felelősségbiztosítási kockázatot, kivéve, ha az ilyen fedezet kiegészíti a fő tevékenységként kínált árut vagy szolgáltatást.

3. Az irányelv meghatározza azokat a tevékenységeket is, melyek nem tekinthetőek értékesítési tevékenységnek (pl. eseti tanácsadás) ${ }^{5}$.

Az IDD a követelményeket arányosan igazítja az egyes csatornák, illetve az általuk forgalmazott termékek jellegzetességeihez. Mindazonáltal kiemelendő, hogy a megerősített fogyasztóvédelem érdekében minimum elvárásokat még a mentesülést élvező értékesítési csatornák esetében is megfogalmaz a megbízó (biztosító/közvetítő) felelőssége mellett. Ilyen például az, hogy az értékesítőnek közölnie kell a biztosító személyét, a panasztétel módját, továbbá biztosítania kell, hogy az értékesítési folyamatban az ügyfél igényeit és szükségleteit figyelembe vegyék.
Az IDD hazai átültetése során a jogalkotónak körültekintően kell mérlegelnie majd, hogy a magyar gyakorlatban létező értékesítési csatornák a fentiek szerinti melyik kategóriába sorolódnak az átültetéskor, illetve hogy az egyes esetekben milyen módon kerül rögzítésre a feltételek arányos alkalmazása az egyes termékcsoportok, illetve értékesítési csatornák vonatkozásában.

Az IDD a követelményeket arányosan igazítja az egyes csatornák jellegzetességeihez.

\section{- Nyilvántartásba vétel, FOS és FOE}

A nyilvántartásba vétel követelményét már az IMD is rögzíti, ez a kötelezettség ugyanakkor nem terjed ki a biztosítókra és alkalmazottjaikra, ahogy jelenleg az IDD hatálya alatt sem terjed ki. Közvetítők esetében föszabályként minden biztosításközvetítői természetes személyt nyilvántartásba kell venni, azonban a tagállamok ettől eltérhetnek, és lehetőség van arra, hogy ne minden természetes személy regisztrációját követeljék meg. Minimum elvárás azonban, hogy legalább az értékesítésért felelős személy nyilvántartásba kerüljön. Új elem, hogy a nyilvántartásnak online rendszerűnek kell lennie, és a tagállami nyilvántartások az EIOPA weboldalán keresztül is elérhetőek lesznek.

Tagállami opció annak lehetővé tétele, hogy a biztosítók együttműködjenek a hatósággal a közvetítők nyilvántartásba vételében, különös tekintettel a kiegészítő biztosításközvetítőkre.

A szöveg egyaránt rögzíti az uniós alapjogokat, a határon átnyúló szolgáltatásnyújtás (FOS, Freedom of Services) és a letelepedés szabadságának (FOE, Freedom of Establishment) jogát, az azokra vonatkozó különös szabályokat. A hatékony fogyasztóvédelem biztosítása érdekében a fogadó és a székhely szerinti tagállamnak szorosan együtt kell működnie a szabályok betartatása érdekében. A szolgáltatásnyújtás szabadsága esetében a fö felelősség a székhely szerinti tagállam hatóságáé, míg fióktelep (vagy más állandó jelenlét) esetén a végrehajtási felelősség megoszlik a két tagállam hatóságai között. Az üzlet egészére vonatkozó kötelezettségek betartatása a székhely szerinti tagállamot terheli, míg a fogadó tagállamnak kell érvényesítenie a tájékoztatási és üzletviteli szabályok betartatását. Ugyanakkor mindkét esetben újdonság, hogy a fogadó tagállam hatósága a korábbinál szélesebb jogosítványokat kap azzal, hogy jogosult lesz a beavatkozásra, ha a székhely szerinti tagállam nem hozza meg a megfelelő intézkedéseket, vagy azok az intézkedések nem bizonyulnak elégségesnek.

Ma még sokszor nehezen áttekinthető a határon átnyúló szolgáltatás végzése kapcsán, hogy melyek azok a tagállami fogyasztóvédelmi, közérdeket szolgáló szabályok, melyek túlnyúlnak a közös, uniós minimumszabályokon. Az IDD rendelkezései értelmében 
ezentúl az EIOPA weboldalának hiperlinket kell tartalmaznia a tagállami hatóságok azon weboldalára, ahol ezek a szabályok elérhetőek, jogi területek szerinti kategóriába sorolva.

\section{- Szervezeti elvárások}

A közvetítőkkel szemben idáig is elvárás volt a megfelelő képzettség, illetve kompetencia, az IDD ehhez további elvárásként szabja a folyamatos képzést is, amelynek legalább az évi 15 órát el kell érnie. A továbbképzés különböző tanulási módokat is magában foglalhat (e-oktatás, mentorálás stb.), a konkrét tagállami elvárásokat pedig a különböző értékesítési csatornákra, illetve forgalmazott termékekre arányosított módon kell alkalmazni. Az elvárt szakmai ismereteket és kompetenciát az IDD 1. sz. melléklete tartalmazza főbb termékcsoportonkénti bontásban.

Tagállami opció. A képzési és továbbképzési követelmények sikeres teljesítése bizonyítvány megszerzéséhez köthető. Továbbá születhet olyan döntés, hogy a folyamatos képzés elvárását a szervezeten belül nem minden természetes személyre alkalmazzák, de azokra mindenképpen alkalmazni kell, akik az értékesítésért felelősek, és akik közvetlenül értékesítéssel foglalkoznak.

Az értékesítővel szemben támasztott jó hírnév elvárása visszaköszön az IMD irányelvből, ahogy a közvetítők esetében a szakmai felelösségbiztosítás vagy az ennek megfelelő vagyoni biztosíték megkövetelése is. Arányos mértékben ezzel a kiegészítő biztosításközvetítői tevékenységet végzőnek is rendelkeznie kell.

További ügyfélgaranciát jelent az az elvárás, hogy a tagállamoknak meg kell tenniük a szükséges intézkedést arra az esetre is, ha a közvetítö nem képes a biztosítási dijat, illetve a biztosító által kifizetett biztosítási összeget továbbítani. Az IDD erre négy megoldást kínál fel, melyek közül a tagállam választhat ${ }^{6}$. Az egyik lehet egy olyan jogszabály, amely megszabja, hogy mikor tekinthető a közvetítő által történő díjtovábbítás, illetve kárkifizetés teljesítettnek. További három lehetőség: a vagyoni biztosíték megkövetelése, az elkülönített ügyfélszámla létrehozása vagy a garanciaalap felállítása.

Második szintü szabályozás. Az EIOPA felhatalmazást kap az irányelvben meghatározott szakmai felelősségbiztosítási és vagyoni biztosíték összegének felülvizsgálatára, valamint szabályozástechnikai sztenderdtervezetek kidolgozására ezen összegek kiigazítása céljából.

A panaszkezelés elvárásai kapcsán új elem, hogy az IDD már kötelezettségként írja elő (a korábbi ajánláshoz képest), hogy a tagállamoknak biztosítaniuk kell a bíróságon kívüli panasztétel és jogorvoslati eljárások kialakítását, melynek során azt is biztosítani kell, hogy a döntés érvényesíthető legyen azokra a biztosításértékesítőkre is, akikkel szemben az eljárást indították. Ez a feltétel teljesíthető a tagállamban már meglévő eljárás felhasználásával is.

\section{- Közös tájékoztatási és értékesítési szabályok az életbiztosításokra és nem-életbiz-} tosításokra

Általános elvárások

A MiFID szabályozásban már megfogalmazott elvárás az élet- és nem-élet ágra egyaránt rögzítésre kerül. Az értékesítőknek becsületes, tisztességes és szakszerü módon kell tevékenykedniük az ügyfeleik legjobb érdekében. Az ügyfelekhez eljuttatott bármilyen tájékoztatásnak tisztességesnek, egyértelmünek és nem félrevezetönek kell lennie, beleértve a marketingközleményeket is.

Fontos új szabály, amelyet a tagállamoknak biztosítaniuk kell, hogy az értékesítök javadalmazása nem történhet ellentétes módon azon kötelezettségükkel, hogy az ügyfeleik legjobb érdekében járjanak el. A szöveg külön kiemeli, hogy nem alkalmazható olyan ösztönzőrendszer, amely arra sarkallná az értékesítőt, hogy egy bizonyos biztosítási terméket ajánljon az ügyfélnek, amikor más, az ügyfél igényeinek jobban megfelelő biztosítási terméket is ajánlhatna. Ezen szabály gyakorlatban történő alkalmazása nagy valószínűséggel kihívásokat tartogat a nemzeti piacok számára, tekintve a biztosítói és közvetítői ösztönzési rendszerek meglévő differenciált megoldásait.

Az IDD tevékenységi alapú szabályozás, nem ismeri a függő és független közvetítö fogalmát.

Az IDD rögzíti a szerződés megkötése előtt az ügyfélnek nyújtandó tájékoztatás tartalmát, ami a közvetítői értékesítés esetében bővebb lista, mint a közvetlen biztosítói értékesítésnél. A legtöbb elvárás ismerős a mostani IMD irányelvből, mindkét fő csatorna esetében ugyanakkor vannak új elemek is.

1. Tájékoztatást kell adni arról, hogy történik-e tanácsadás az értékesítés során. A jogszabály tanácsadás fogalma alatt személyes ajánlást ért egy vagy több biztosítói szerződésre vonatkozóan akár az ügyfél kérésére, akár a biztosításértékesítő kezdeményezésére. A közvetítő esetében arra is ki kell térni, hogy a tanácsadás tisztességes és személyre szóló elemzés alapján történik-e, illetőleg, hogy a közvetítő mely biztosítókkal milyen jellegű kapcsolatban áll.

2. Szintén új elvárás, hogy tájékoztatást kell adni legalább a javadalmazás termé szetéről, közvetítők esetében annak forrásáról, illetve a díj összegéről is (vagy kiszámításának módjáról), amennyiben azt az ügyfél fizeti. Biztosítói értékesítés esetében 
is elvárás, hogy az értékesítő feltárja a javadalmazás természetét (a javadalmazás forrása biztosítói értékesítés esetén egyértelmünek tekinthető). Ezen elvárás oka az, hogy ennek hiányában abban lehetne érdekelt a biztosító, hogy inkább közvetlenül értékesítsen az ügyfeleknek és ne közvetítőn keresztül.

Az általános szabályok tehát különbséget tesznek a biztosítói és a közvetítői értékesítés között ebben a vonatkozásban. Ugyanakkor a későbbiekben látni fogjuk, hogy a PRIIPs termékek megerősített szabályainál - amennyiben az összeférhetetlenség szervezeti megoldása nem bizonyulna elégségesnek - az IDD a biztosítói értékesítésnél is elvárja, hogy az összeférhetetlenség (jellemzően javadalmazás) természetének közlésén túlmenően az összeférhetetlenség forrásáról is tájékoztatás történjen.

Az IDD tevékenységi alapú szabályozás, nem ismeri a függő és független közvetítő fogalmát, ugyanakkor az összeférhetetlenségi szabályok közt előírja a közvetítő és az egy vagy több biztosító közti kapcsolat feltárásának kifejezett kötelezettségét. Az irányelv az értékesítés különböző szintjeit azonosítja, melyeket a tanácsadás meglétéhez, illetve annak szintjéhez köt az alábbiak szerint.

1. Minden esetben elvárt az igényfelmérés és termékismertetés, amelynek a termék összetettségéhez és a fogyasztó által viselt pénzügyi kockázathoz kell igazodnia. Az alapeset tehát a tanácsadás nélküli értékesítés.

2. Amennyiben tanácsadással történik az értékesítés, ott személyre szabottan el kell magyarázni, miért éppen azt a terméket ajánlotta a közvetítő, és az hogyan felel meg az ügyfél igényeinek.

3. Amennyiben a tanácsadás tisztességes és személyes elemzés alapján történik, akkor a piacon elérhető biztosítási termékek „elég nagy számát” kell elemeznie a közvetítőnek.

A hazai átültetés során feladat lesz annak pontos meghatározása, hogy miben különbözik egymástól a tanácsadással és tanácsadás nélküli értékesítés, különös tekintettel arra, hogy az ügyféligény felmérése és ennek fényében a termékmegfelelés biztosítása bármely esetben alapelvárás. Kérdés továbbá az is, hogy mindez miképpen illeszkedik a Biztosítási törvény által alkalmazott függő és független közvetítői kategóriákhoz.

Tagállami opció. A tanácsadás kötelezővé tehető akár azösszes termék, akár bizonyos termékcsoportok vonatkozásában. Külön kiemelésre kerül, hogy ilyen szigorítás esetén a szabályok a határon átnyúló szolgáltatókra is vonatkoznak.

További nevesített tagállami opció a harmadik fél javadalmazásának korlátozása vagy tiltása. Ez a lehetőség a tisztességes és személyre szabott elemzés alapján történő tanácsadás esetében merülhet fel.

\section{Kiemelt információkat tartalmazó dokumentum}

Az életbiztosítással foglalkozók már jó ismerősként üdvözlik a KID betűszót (Key Information Document), azaz a kiemelt információkat tartalmazó dokumentumot, melynek alkalmazását a PRIIPs rendelet írja elő 2017. január 1-jétől a biztosítási alapú befektetési termékekre (is). A rövid ügyféldokumentummal a jövőben a nem-életbiztosítások kialakítóinak és értékesítőinek is meg kell barátkozniuk, mivel ezen termékeknél is egy uniós szinten egységesített dokumentumot kell átnyújtani az ügyfélnek az IDD szabályok szerint. Amíg nem alakul ki a megnevezés magyar megfelelője, addig a szakma jellemző módon a KID analógiájára a PID elnevezést használja erre a dokumentumra (Product Information Document). A PID-del szemben támasztott elvárásokat az IDD felsorolja, ugyanakkor könnyen belátható, hogy annak elkészítése a gyakorlatban nem lesz egyszerü, mivel rendkívül változatos termékcsoportról beszélünk (kgfb, casco, lakás-, utas-, baleset- és betegségbiztosítás stb.).

Második szintü szabályozás. Az EIOPA felhatalmazást kap a PID egységes megjelenítési formájára vonatkozó végrehajtás-technikai sztenderdtervezetek kidolgozására, amelyet 2017. február 23-ig nyújt be a Bizottságnak. A Bizottság ezt követően végrehajtási rendeletet fogad el.

Ügyfél-tájékoztatás módja

Az ügyfél-tájékoztatást föszabályként papíron, térítésmentesen kell teljesíteni. A kor szellemével haladva ugyanakkor módot ad a jogszabály arra, hogy az ügyféligénnyel összhangban más tartós adathordozón is megtörténhet a tájékoztatás, amely adott esetben lehet weboldal vagy más elektronikus kommunikációs eszköz. Ügyfélkérésre ugyanakkor a papíralapú tájékoztatást mindenkinek teljesítenie kell.

\section{Keresztértékesités szabályai}

A keresztértékesítés Unió-szerte gyakran alkalmazott stratégia. Ez többnyire előnyökkel jár az ügyfél számára, de előfordulhat olyan eset is, amikor az ügyfél igényei nem elégséges módon kerülnek mérlegelésre. A jelenleg hatályos IMD szabályozáshoz képest feltétlenül új elem a keresztértékesítés szabályainak rögzítése. Az IDD előkészületi szakaszában nagyon határozott szigorítási törekvések voltak, melyek a végső szövegben alapelvárásként nem jelennek meg, ugyanakkor, mint látni fogjuk, feltűnnek a nevesített tagállami opciókban.

Mindenekelőtt rögzítésre kerül, hogy a több kockázatot is tartalmazó biztosítási termékeket (mint pl. utasbiztosítás, lakásbiztosítás) nem érintik ezek a szabályok. A 
rendelkezések arra az esetre vonatkoznak, ha a másik csatolt termék nem biztosítás, és ezen belül is két eset kerül nevesítésre.

a) Amennyiben a biztositás fötermék, és azt egy nem biztositási kiegészítő termékkel együtt kínálják, akkor arról kell tájékoztatni az ügyfelet, hogy van-e lehetőség az elemek külön-külön történő megvásárlására, és ha igen, akkor mennyi az elemek egyenkénti díja.

b) Amennyiben a biztositás a kiegészitö termék, akkor a másik nem biztositási termék külön történő megvásárlását fel kell ajánlani az ügyfélnek.

Figyelmet igényelnek ugyanakkor a kapcsolt termékekre vonatkozó - nem az IDD-ben szabályozott - további keresztértékesítési rendelkezések is, mivel a biztosítási termékeknél alkalmazásra kerülő keresztértékesitési gyakorlat nem sértheti más termékre vonatkozó uniós keresztértékesítési szabályok alkalmazását (ld. MiFID termékek, Mortgage Credit Directive).

Tagállami opció. A tagállam a keresztértékesítés szabályaira a fentinél szigorúbb szabályokat határozhat meg, ami akár a keresztértékesítés tilalma is lehet, amennyiben a gyakorlat hátrányos a fogyasztóra nézve.

Harmadik szintü szabályozás. Az EIOPA iránymutatást dolgozhat ki a kereszteladások felügyeleti gyakorlatára.

\section{Termékfelügyelet és irányitás követelménye}

Szintén új elem annak az elvárásnak a rögzítése, miszerint a termék gyártójának és értékesítőjének a termék minden életszakaszában ellenőrzési rendszert kell müködtetnie, ami biztosítja, hogy a termék bármely vonatkozásban (termékdesign, marketinganyagok, értékesítési stratégia és csatorna stb.) megfelel a célpiac igényeinek, illetve jellegzetességeinek (Product Oversight Governance, POG). Elvárt a kapcsolódó folyamatszabályozás, dokumentáltság, hogy az bármikor ellenőrizhető, auditálható legyen. Az elvárás nem vonatkozik a nagykockázatokra.

Másodikszintü szabályozás. A Bizottság felhatalmazást kapott végrehajtási rendelet elfogadására, a termékfelügyeletre és irányításra vonatkozó elvárások részletszabályainak meghatározása érdekében. A végrehajtási rendelet előkészítését szolgáló technikai javaslatot az EIOPA 2017. február 1-jéig nyúitja be a Bizottság számára.

A részletszabályok tehát második szinten, végrehajtási rendeletben rögzülnek majd. Mindazonáltal célszerű arra figyelnie a szakmának, hogy az április elején megjelent EIOPA-iránymutatás a termékfelügyelet és irányítás követelményeinek való megfelelést - igaz csak „soft law”, iránymutatás formájában - előrehozza az IDD irányelv 2018. februári alkalmazási határidejéhez képest.

\section{- Megerősített PRIIPs termékszabályok}

A korábbiakhoz képest a legjelentősebb változásokat ezen a területen fogadták el. Fontos, hogy ezt a fejezetet az érintettek körültekintő módon elemezzék, mivel az abban foglaltak jórészt a már meglévő MiFID rendelkezések szó szerinti átemelésével születtek. A magyar jogalkotónak, illetve biztosítási szakmának meg kell tehát birkóznia a kihívással, hogy a tisztán befektetési termékekre kitalált szabályokat a biztosítási termékekre is alkalmazható módon ültesse át a gyakorlatba. A feladatot az is nehezíti, hogy a bevezetőben említett tagállami kompromisszumok ebben a fejezetben csapódtak le leginkább olyan megszövegezésben, melynek pontos és aggálytalan értelmezése próbára teszi majd a magyar jogalkotót.

A biztosítási alapú befektetési termékeket gyakran más befektetési termékek (pl. befektetési jegy, strukturált betét) lehetséges alternatívájaként kínálják az ügyfélnek. A befektetői védelem biztosítása és a szabályozási arbitrázs megelőzése érdekében az IDD ezen biztosítási termékek szabályozását hozzáigazítja a befektetési termékekhez, kézenfekvő módon a már meglévő MiFID-szabályokhoz. Ezekhez a közös szabályozási alapelvekhez tartoznak az érdekkonfliktus kezelésének szervezeti szabályai, a megemelt tájékoztatási és tanácsadási követelmények, illetve a javadalmazással kapcsolatos korlátozások.

\section{A biztosítási alapú befektetési termékek IDD szabályozását}

\section{hozzáigazítja a MiFID-szabályokhoz.}

A biztosítások esetében a szóban forgó termékcsoport a biztosítási alapú PRIIPs termékek csoportja, melynek IDD-beli meghatározása megfelel a PRIIPs rendelet vonatkozó meghatározásának. Ez a kör felölel minden életbiztosítási terméket, ahol a kockázati fedezet megtakarítási elemhez kapcsolódik. Ebből a körből lényegében csak a tisztán kockázati tartalommal rendelkező és jellemző módon halálesetre szóló biztosítások maradnak ki.

És akkor lássuk a részleteket: melyek a megemelt elvárások ennél a termékcsoportnál?

Összeférhetetlenség megelözése és kezelése

A szervezeten belül adminisztratív intézkedéseket kell fenntartani annak érdekében, hogy az ügyfelekérdekeit kedvezőtlenül érintő összeférhetetlenség megelőzésre kerüljön. Amennyiben ezek a szervezeti és igazgatási intézkedések nem bizonyulnak elegendőnek, akkor a biztosítást értékesítőnek a szerződés megkötése előtt kellő időben és egyértelműen kell tájékoztatnia az ügyfelet az összeférhetetlenség általános jellegéröl vagy forrásairól.

Második szintü szabályozás. A Bizottság felhatalmazást kap arra, hogy az érdekkonfliktus kezelésének részletszabályait végrehajtási rendeletben pontosítsa. A végrehajtási rendelet előkészítését szolgáló technikai javaslatot az EIOPA 2017. február 1-jéig nyújtja be a bizottság számára. 


\section{Ügyfelek tájékoztatásának megerösitett szabályai}

A közös élet és nem-élet szabályokhoz képest többletként fogalmazódik meg az elvárás, hogy az ügyfelet a szerződés megkötése előtt tájékoztatni kell az összes költségről és kapcsolódó díjról, mely tájékoztatásnak az alábbiakat kell magában foglalnia.

a) Tanácsadás nyúitása esetén azt, hogy történik-e rendszeres értékelés az ügyfélnek ajánlott befektetési termék alkalmasságáról.

b) Tájékoztatás a befektetési termékről és az ajánlott befektetési stratégiákról, beleértve a kapcsolódó kockázatokra történő figyelemfelhívást.

c) Minden értékesítésre vonatkozó információ, beleértve a tanácsadás és termék költségéről történő tájékoztatást, az ügyfél általi fizetés módját, beleértve az esetlegesen harmadik féltől származó fizetéseket is.

A költségekről történő tájékoztatást összesített formában kell nyúitani annak érdekében, hogy az ügyfél megérthesse annak hatását a befektetése hozamára. Amennyiben az ügyfél ezt kéri, a költségeket tételes bontásban is be kell mutatni. Adott esetben ezt a tájékoztatást rendszeresen (legalább évente) biztosítani kell az ügyfélnek.

Figyelnie kell, hogy az IDD elvárásai ne eredményezzenek

\section{ismétlődéseket a tajékoztatásban.}

Ezen a pontot mindenképpen emlékeztetni kell a korábban már említett KID dokumen tumra. A KID egy uniós szinten egységesített - így az összehasonlíthatóságot is biztosító, - rövid tájékoztató ügyféldokumentum, mely tartalmazza a befektetési termék legfontosabb tudnivalóit, úgy mint kockázat, hozamszcenáriók, költségek, illetve általános terméktájékoztatás. A KID-et 2017. január 1-jétől kötelezően kell alkalmazni az érintett termékcsoportra, ezen belül a biztosítási alapú PRIIPs termékekre is. Mivel a KID a fenti elvárások java részét teljesíti, az irányelv átültetése során figyelnie kell a jogalkotónak arra, hogy az IDD elvárásai ne eredményezzenek ismétlődéseket a tájékoztatásban. (Ennek kapcsán érdemes megjegyezni, hogy kissé érthetetlen módon, az IDD ennél a résznél nem tesz hivatalos utalást az irányelv elfogadásakor már hatályban lévő PRIIPs rendeletre.)

Harmadik fél javadalmazása

Az IDD történetének egy korai szakaszában valós opcióként merült fel a harmadik fél általi (ügyfél érdekében eljáró fél) javadalmazás egyértelmű tiltása a biztosító/közvetítő részéről. Ez a szigorú tiltás a tárgyalások végére annyiban enyhült, hogy a harmadik fél javadalmazásának lehetőségét az IDD - az összeférhetetlenség és átláthatóság szabályainak érvényesülésén túl - kettős feltételhez köti. a) A javadalmazás nem gyakorol káros hatást az ügyfélnek nyújtott szolgáltatás minőségére.

b) Nem gátolja az értékesítőt abban, hogy becsületesen, tisztességesen, szakszerüen és az ügyfelei legjobb érdekében járjon el.

\section{Nevesített tagállami opciók}

- Megtiltható vagy tovább korlátozható a biztosítási tanácsadással kapcsolatos javadalmazás harmadik féltől történő elfogadása

- A tanácsadás nyújtása kötelezővé tehető a biztosítási alapú befektetési termékek vagy azok bizonyos típusainak értékesítése esetében.

- Független tanácsadás esetén előírható, hogy a közvetítőnek a piacon elérhető, kellően nagy számú, típusát és termékszolgáltatóit tekintve eléggé sokféle biztosítási termékértékelését el kell végeznie, ami nem korlátozódhat azokra a termékekre, amelyeket a közvetítővel szoros kapcsolatban álló termékgazdák nyújtanak.

Másodikszintü szabályozás. A Bizottság felhatalmazást kapott, hogy végrehajtási rendeletben pontosítsa a harmadik fél javadalmazásának részletszabályait. A részletszabályok véglegezésekor figyelembe kell venni a fogyasztónak nyúitott szolgáltatás, illetve termék jellegét is. A végrehajtási rendelet előkészitését szolgáló technikai javaslatot az EIOPA 2017. február 1-jéig nyúitja be a Bizottság számára.

Ügyfélalkalmasság és megfelelés értékelése

Ezek az elvárások is a MiFID-szabályozás nyomán születtek. Habár az IDD nem írja elő az ügyfelek kategorizálását, azt elvárja, hogy az értékesítő felmérje az ügyfél kapcsolódó ismereteit, pénzügyi helyzetét, kockázattürő képességét.

a) Tanácsadással történő értékesítés esetén az ügyfél alkalmasságának értékelését el kell végeznie az értékesítőnek annak érdekében, hogy a fentiek szerint meghatározott ügyféligénynek megfelelő befektetési terméket ajánlhasson.

b) Tanácsadás nélküli eladás esetén az ügyfél megfelelési vizsgálatát kell elvégezni annak eldöntése érdekében, hogy a tervbe vett biztosítási termék vagy szolgáltatás megfelelö-e az ügyfél számára. Ha az értékesítő úgy ítéli meg ennek alapján, hogy a termék nem megfelelö az ügyfél számára, akkor őt erre figyelmeztetni kell. Amennyiben az ügyfél nem adja meg a kívánt tájékoztatást, akkor az értékesítőnek arra kell figyelmeztetnie, hogy nem tudja megállapítani, hogy a szóban forgó termék megfelelö-e a számára.

Elvárja, hogy az értékesítő felmérje az ügyfél kapcsolódó ismereteit, pénzüigyi helyzetét.

A MiFID-szabályozásban jelenleg meglévő „execution only”lehetősége nem alaplehetőségként szerepel az IDD szövegben, hanem nevesített tagállami opcióként. 
Tagállami opció. Egy szigorú feltételrendszer egyidejű teljesülése esetén lehetővé válik, hogy az ügyfél-megfelelési vizsgálat elvégzése nélkül is értékesíthető legyen biztosítási alapú befektetési termék. A négy elemből álló feltételrendszer lényege, hogy a szóban forgó termék ne legyen összetett, ami megnehezítené a kockázatok megértését, az értékesítést az ügyfél kezdeményezze, az ügyfél tisztában legyen azzal, hogy nem részesülhet a vonatkozó fogyasztóvédelmi szabályok által nyújtott védelemben, továbbá az értékesítő teljesíti az összeférhetetlenségre vonatkozó elöírásokat ${ }^{7}$.

Másodikszintü szabályozás. A Bizottság felhatalmazást kap arra, hogy végrehajtási rendeletben szabályozza az alkalmassági és megfelelési vizsgálat során beszerzendő információkat, továbbá az „execution only” lehetőség előfeltételei között szereplő „nem összetett” biztosítási alapú befektetési termék alkalmazásának feltételeit. Ennek során figyelembe kell venni az ügyfélnek kínált termék, illetve szolgáltatás jellegzetességeit, valamint az ügyfél lakossági vagy szakmai voltát. A végrehajtási rendelet előkészítését szolgáló technikai javaslatot az EIOPA 2017. február 1-jéig nyújtja be a Bizottság számára.

Harmadikszintü szabályozás. AzEIOPA 2017. augusztus 23-ig iránymutatást dolgoz ki azon termékek értékelésére vonatkozóan, melyek szerkezetükből adódóan megnehezítik az ügyfél számára a kapcsolódó kockázat megértését.

Továbbá az EIOPA iránymutatásokat dolgozhat ki a nem összetettnek minősülő biztosítási alapú termékek értékelése tekintetében.

Nyilvántartás és beszámoló az ügyfelek számára

Nevesített kötelezettség az ügyfélnyilvántartások létrehozása, továbbá rendszeres beszámolók rendelkezésre bocsátása az értékesítő által nyúitott szolgáltatásokról, a kapcsolódó költségekről. Tanácsadás esetén az alkalmasságra vonatkozó nyilatkozatot is az ügyfél rendelkezésére kell bocsátani, melyben az értékesítő részletezi, hogy a tanácsadás milyen módon felel meg az ügyfél igényeinek. Ha az értékesítő az eladáskor arról tájékoztatta az ügyfelet, hogy rendszeresen elvégzi az alkalmasság értékelését, akkor az időszakos beszámolónak a vonatkozó frissített alkalmassági nyilatkozatot is tartalmaznia kell.

Második szintü szabályozás. A Bizottság felhatalmazást kapott arra, hogy végrehajtási rendeletben szabályozza az ügyfélnyilvántartások és beszámolók tartalmát és formátumát, figyelembe véve az ügyfél számára kínált termék, illetve szolgáltatás jellegét, valamint az ügyfél lakossági vagy szakmai voltát. A végrehajtási rendelet előkészítését szolgáló technikai javaslatot az EIOPA 2017. február 1-jéig nyújtja be a Bizottság számára.

\section{- Szankciók}

A tagállamoknak hatékony, arányos és visszatartó erejủ közigazgatási szankciókat és egyéb intézkedéseket kell elöírniuk. Ebbe beleértendő az olyan pénzbírságok megállapítása is, melyek kellően magasak ahhoz, hogy az intézmények és azok vezetői számára visszatartó erővel bírjanak A hatóság elmarasztaló határozatát az átláthatóság érdekében közzé is kell tenni, kivéve azokat az eseteket, amikor a közzététel veszélyeztetné a pénzügyi piacok stabilitását, vagy a közzététel aránytalan kárt okozna az érintett feleknek.

\section{• Összegzés}

Ezek tehát az elsődleges és legfontosabb tudnivalók az új európai uniós szabályozásról, az IDD-ről, mely a biztosítások értékesítésének legfontosabb szabályozása. A hazai átültetést szolgáló Bit. módosítás szakmai tervezete várhatóan 2017 első félévében készül el, miután ismertté válnak a jelenleg még készülő második szintű szabályok. A magyar jogalkotónak tehát egy év ál rendelkezésére, hogy értelmezze és a hazai viszonyokra ültesse át az uniós szabályozást. Ebben a munkában segítheti a jogalkotót a biztosítási szakma azzal, hogy alaposan tanulmányozza, értelmezi az új irányelv szövegét, az abban megfogalmazott elvárásokat, és azokat összeveti a jelenlegi hazai szabályozással, illetve a biztosítási piac magyarországi jellegzetességeivel.

\section{IRODALOMJEGYZEK}

Az Európai Parlament és a Tanács 2016/97 irányelve a biztositási értékesitésről (IDD irányelv)

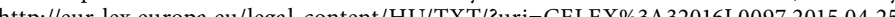

Final Report on Public Consultation on Preparatory Guidelines on product oversight and governance arrangements by insurance undertakings and insurance distributors

https://eiopa.europa.eu/Pages/Consultations/EIOPA-CP-15-008-Consultation-Paper-on-POG-Guidelines-for-insurance-undertakings-and-insurance-distributors-aspx 2015.04.25.

Az Európai Parlament és a Tanács 1286/2014/EU rendelete a lakossági befektetési csomagtermékekkel, illetve a biztositási alapú befektetési termékekkel kapcsolatos kiemelt információkat tartalmazó dokumentum ról (PRIIPs rendelet)

http://eur-lex.europa.eu/legal-content/EN/TXT/?uri=celex\%3A32014R1286 2015.04.25,

A cikk jelentős mértékben támaszkodik az Insurance Europe belső munkaanyagaira, illetve az ott szerzett személyes tapaszta-

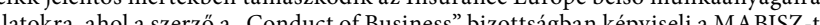

\section{HIVATKOZÁSOK}

'Directive 2016/97 of the European Parliament and of the Council in insurance distribution (IDD)

${ }^{2}$ A PRIIPs rendeletrő̉l részletes írás olvasható a Biztositás és Kockázat II. évfolyam 3. számában http://www.mabisz.hu/images/ A PRIIPs rendeletrol reszletes iras olvashato a Biztositata es Kockazat II. evfolyam 3. szamaban http://ww
stories/docs/biztositas-es-kockazat/2_3/biztositas-es-kockazat-2-evf-3-szam-2-cikk.pdf 2015.04.25.

${ }^{3}$ Éves biztositási dij nem haladja meg a 600 EUR-t, ill. a 200 EUR-t, amennyiben a szolgáltatás időtartama nem több, mint 3 hónap.

További részletek az I. fejezet 1. cikk (3) bekezdésében találhatóak.
${ }^{4}$ Részletek az I. fejezet 2. cikk (1) bekezdés 4. pontjában találhatóak

${ }^{5}$ Részletes felsorolást ld. I. fejezet 2. cikk (2) bekezdésben.

${ }^{6}$ Részletek a IV. fejezet 10. cikk (6) bekezdésben találhatóa

'Pontos részletek a VI. fejezet 29. cikk (3) bekezdésében. 